\title{
Developing Cooperative Learning Video for Studying Economics at Senior High School
}

\author{
Armiati $^{1)}$, Rose Rahmidani ${ }^{2)}$ \\ Dept. Economic Faculty \\ State University of Padang, \\ Padang, Indonesia \\ 1)mia.feunp@gmail.com \\ ${ }^{2)}$ rose_rahmadani@yahoo.com
}

\begin{abstract}
This study aims to products produced in the form of video of cooperative learning for high school economics teachers using Student Team Achievement Division (STAD) methods combined with Course Review Horay (CRH) methods at the material of the price balance. Design of this study is development research (Research and Development, R \& D). Data analysis technique using descriptive and qualitative analysis. The results of this study: 1) Video of cooperative learning as a reference for high school economics teachers to perform more varied learning in the classroom. 2) Based on the assessment of the experts, it is known that this instructional video included in the category of decent and usable. 3) teacher responses in field test shows that teachers provide good feedback so instructional video is feasible and can be used as an alternative in teaching.
\end{abstract} $S T A D$

Keyword: Cooperative Learning Video, CRH,

\section{INTRODUCTION}

The availability of current concepts in teaching and learning is not a new issue in education. However, the availability does not guarantee the numbers of its implementation. Although various concepts are available, many teachers apparently do not yet change the way they conduct their classes. Mostly, many of them prefer to implement conventional learning using the chalk and talk approach.

Generally, topics related to being a competence and professional teachers have always been interesting to talk. The results of teachers' competency test even uncover what has been long hidden in the education in Indonesia. The ministry of education in Indonesia launched the results of teachers' pre-competency test in 2012. Based on the result, it is found that the mean scores obtained by most teachers are 42.25 . The highest score was 97.0 while the lowest was 1.0 .
Based on these two issues, there are two different inseparable problems occur: 1) the competency limitation; a) major category, many teachers do not have proper knowledge and skill in applying current concepts of teaching and learning. Therefore, they rely more on the conventional concept; b) minor category, it is better than the former category, the teachers already know the current concepts, but they are doubt to apply them in the class. They probably can implement one-ortwo methods, but they need many improvements. 2) The motivation problem. For the second problem, the teachers may understand the concepts and know how to apply the concepts in the classroom, but many are not motivated to do it [1]. This problem has been widespread in West Sumatera.

One way to solve this problem is by improving the teaching quality in the classroom. It is necessary for the teachers to be creative so that when they want the students to study Economics, for instance, they can have an interesting, factual and contextual way of teaching that can optimize students' roles in the class. This research is conducted in order to provide a solution dealing with the teachers' limitation during teaching and learning Economics in the class. The research is to develop a learning video that can assist the teachers in implementing cooperative learning. The decision to use learning video is made based on two main considerations. Firstly, many teachers can use the video. The teachers can learn the content of the video as much as they want. Secondly, the video shows the real implementation of the method. The teacher can directly see the examples in the video. That way, they can learn better.

The learning method implemented in the video is cooperative learning. The method is chosen since it is considered simpler; it has various techniques so that more options are available alongside with the studentcentered approach. Moreover, since the content of learning Economics is more about the concepts and principles, where the empirical data are widely spread 
in the society, the cooperative learning gives an opportunity to explore the content and the materials, to collaborate with the students and to minimize unfair competition among them.

The effectiveness of implementing cooperative learning in improving the learning quality has been empirically tested by various researches. Some researchers conclude that the cooperative learning can improve students' motivation as well as their outcomes. The teachers also give positive feedback about the cooperative learning that they did. The teachers noted that students have positive respond about their small group of study, and it helps them to manage their courses [2]. The cooperative learning STAD type in the Economics study lets the students be more positive in learning, help them to achieve a better outcome, and motivate them to improve. The cooperative learning is more effective than the chalk and talk approach. It is seen from the students' outcomes [3], [4]. Cooperative learning done in the Physical study provides more benefits. It is seen from the aspect of students' roles, students' communication ability and students' teamwork, which are improved [5].

The previous research proves that the implementation of cooperative learning gives positive influence and helps teachers to conduct a better teaching and learning process. It is obvious that in the curriculum of 2013, and the ministerial regulation no. 65 the year 2013 about the Standard Process in the part of implementation state: The learning process is done interactively, it is inspiring, interesting, challenging and motivating the students to actively participate [6], [7], [8], [9]. It opens the opportunity to develop students' creativity, independence in line with their talents, interests and physical and psychological development. Cooperative learning is one of the alternatives that teachers can use in order to apply the curriculum of 2013. Furthermore, the success of this method depends on teachers' ability in implementing the cooperative learning especially in the studying of Economics.

\section{RESEARCH METHODS}

The design of this research was Research and Development. The procedures consisted of several phases: planning, exploring, developing the initial product, validating and finalizing. The first phase; planning, was arranging and preparing the video for cooperative learning for Economics teachers. The exploration phase covered literature study and field study. This phase was done by identifying and analyzing the instructional standard competency and basic competency in Economics for senior high school. After that, the storyboard and script were made. The third phase; developing initial product included producing a video of cooperative learning for Economics teachers at senior high school. The next phase was validating which included testing the design, testing the video, experts' reviews toward the cooperative learning video. The research was conducted at Vocational High School 4 Padang. The data used in the research were both qualitative and quantitative data obtained from the experts and the teachers. The data collected included instructional and performance aspects obtained from interviews; suggestions, critics both from the experts and the teachers. The quantitative data covered the quality of the interactive $C D$ used obtained from the respondents through questionnaires which were analyzed using Likert scale and descriptive statistics.

The data were analyzed by using descriptive analysis and qualitative. The descriptive analysis used statistics descriptive; mean scores that used to describe and interpret the data, which were obtained from the questionnaires. The qualitative data were obtained from the interviews, which then were analyzed by using the model of Milles and Huberman [10].

\section{RESEARCH FINDINGS AND DISCUSSIONS}

The learning video was made in order to complete the demands of the 2013 curriculum that requires teachers to be able to have learning activity, which encourages students to be active, creative, and innovative. The research was done based on the phases and steps that have been previously explained.

The video production processes included video shooting that was based on the storyboard and the script. The video shooting was an interpreting phase. It was to converse what has been written in the script into an actual visualization on a screen. The video produced was not directly sent to the developing phase. The format of the video and the audio were adjusted to the supporting hardware to make it users friendly. Then, the video was edited and mixed. The editing and mixing process were done as how the storyboard stated. In the editing process, the best shoots were decided. Moreover, the lighting and the animating set such as adding the text or sound effect were other activities in the editing process.

Once the editing process was done, the next activity was mixing. It was to combine the narrator records with the video that has been edited. After combining the narration, instruments and sound effect with the video, then the voice of the narrator and the instruments were adjusted. Once the editing process finished, the records were burned into a CD/DVD. 
The results of the cooperative learning combined with STAD and Course Review Hooray model were explained in the following details: a) the teacher stated the intended competencies, b) the teacher had an question and answer session, c) the teacher presented the material, d) the teacher put the students in the group of 4-5, e) the teacher provided some tasks that every group had to complete. Each member of the group ensured that everybody in the group understood, f) the teacher gave a quiz or questions to all students, g) to check the students' correction, the students were asked to provide spaces for the answer.

The spaces were made in the form of a table consisted of nine, sixteen or twenty-five boxes. The numbers of the box depended on the need. Every box was filled with any number. h) The teacher read the questions in random based on the numbers which had been set before. The students wrote the answers on the box that had the same number with the question that the teacher mentioned. The question mentioned by the teacher was directly discussed. If the answer was right then the check (v) was given and if it was wrong then the (x) was given. In this part, the students' honesty was needed in answering the questions. i) The students who had got checks (v) either vertically, horizontally, or diagonally should say "hurray" or other yelled loudly. j) The students' scores were calculated from the corrects answers and the "hurray" they yelled. k) Rewarding students. 1) At the end of the session, the conclusion was derived both from the teacher and the students.

The reliability of the video was obtained from the result of the reliability test using the video assessment criteria provide by Riyana [11]. In this research, the media experts were asked to assess the presentation of the cooperative learning video. The assessment was based on the evaluation sheets that had been prepared before. The video was rated as usable if the score was more than $69 \%$. If the score was lower than that, the media should be fixed, and then it should be validated on step II.

Based on the evaluation made by expert 1 , the score obtained for the video was $82.35 \%$. The reliability percentage concluded that the video was usable. Based on some suggestions given by expert 1 , it was necessary to have the video occupied with the ability to zoom in and zoom out so that some acts could be better maximized. It was also expected that the users could participate in the learning process and add users interaction quality with learning materials. After a discussion with the expert 1 , it was decided that the video did not need to be occupied with 'participation and interaction' with the users since it was a one-sided video where there was no possibility to participate or to interact with the users.
Based on the evaluation made by expert 2, the score obtained was $83.53 \%$. The video was considered usable. Expert 2 stated some possible suggestions dealing with the LCD used during the teaching and learning process. When the LCD was turned on, the brand of the LCD was shown. According to the expert 2 , the brand might give an impression that the video had hidden-planned advertisement. Therefore, it was suggested that the brand should be blurred. Then, it was also suggested for term 'STAD'. Sometimes, the word was pronounced as a single word; STAD, while sometimes, it was pronounced S-T-A-D; the word was spelled. Expert 2 considered this as an inconsistency. Therefore, the term should be said consistently.

The last suggestion made by the expert 2 was about the introduction that bridged the students to the video. According to the expert 2, the introduction was made to point out that the learning video was addressed to the Economics teachers that had the intention to have the students participated actively in the class.

The suggestions given by expert 3 were about the use of the learning video in studying Economics. The score for the video was 92.94. The category was usable. However, some parts of the video needed to be revised or fixed. The duration of the video should be shortened and some learning evaluation in the video should be added. According to expert 3, the duration can be shorter. Then, the evaluation should be put at the end of the video. Yet, due to the evaluation had been reflected in the learning process, then, the researcher did not add any evaluation. In addition, the video was meant to help the teachers not to see the students' outcomes.

Although the video was already in the category usable, as what had been agreed by the experts, the video then, had also been revised based on the suggestions given. The revisions were made to have better quality of a learning video. It is in line with the statement delivered by Riyana [11] that to have a learning video, which can improve users' motivation and effectiveness, then in the process of its development, the video should consider some characteristics and some criteria. The characteristics are 1) clarity of the message. 2) Stand alone, 3) users friendly, 4) representative 5) media visualization, 6) high resolution, and 7) able to be used either classical or individual.

Then based on the evaluation given by the 10 Economics teachers, the percentage obtained for the video was $86 \%$. The category was usable. There were some suggestions given by the teachers related to the cooperative learning video developed. According to them, the video was interesting seen from its content and its display. The video had been arranged based on the curriculum; therefore, it was clear and easy to 
understand. The materials were also arranged systematically, began with the simpler topic up to the complex one. Some details that most teachers paid attention to were the reinforcement, the expansion of the material, the rewards and the grading system. Moreover, the teachers found the video to be helpful since they could understand more about how to apply the model. They could find the solution for the problems that they might find when they tried to understand the model from the books. They stated that they were keen to apply the video in their own class.

The presentation of the learning video is relevant and helps teachers to understand the learning model used. The video can be learned classically or individually. The video motivates the teachers to be active and to use it in the teaching and the learning process in their own classes. The video is inspiring. Actually, there are a lot of cooperative learning models that teachers can use in the class. Yet, this model, that is STAD and Course Review Horay are two simple and understandable learning models. These two models can encourage the students to learn more, to activate and to develop their thinking. It also inspires the students to have positive activities, which can be explored through discussion or group work. Therefore, it is important for the teachers to use the video in order to understand the cooperative learning model.

Two reasons why cooperative learning is important, they are 1) research show that the cooperative learning can improve students' learning outcomes, social relation, self-awareness, and honor. 2) Cooperative learning can help students to learn to think, solve problems and integrate knowledge and skill [12]. Based on this statement, it can be said that cooperative learning gives contribution for the teachers so that they can help their students who mostly have problems with the achievement.

The learning video as a learning material aims to 1) clarify and ease the presentation of the learning materials so that it is not too verbal., 2) Cope with the limitation of time, space, and senses of the students or the instructors, 3) use it concisely and variously [10]. Based on this statement, it is possible to say that the cooperative learning video, made for the Economics teachers of senior high schools, can help the teachers to understand the learning model. The video can cope with all limitation faced by most teachers in understanding a learning model explained by a book. The video can be learned classically, or individually. Therefore, the video is very usable and appropriate to be taken as a learning media.

\section{CONCLUSION AND SUGGESTIONS}

Based on the explanation stated in the previous chapters, the possible conclusions are: 1) the research is to produce a learning media, that is a cooperative learning video that contains learning scenes occurs in a classroom, 2) through the validation sheets filled by the three education technology experts, the scores obtained were: $82.35 \%, 83.53 \%$, and $92.94 \%$. The scores put the video in the category of usable. 3) Through the reliability test completed by the 10 Economics teachers, the mean score obtained was $86 \%$, the category was usable, and the video could be used as an alternative to teach.

Some possible suggestions for the research are: 1) some supporting supplements are needed for this cooperative learning video so that the teachers can easily understand and use it. 2) For the teachers, the video should be used as an alternative for teaching. 3) For researchers, to develop a learning video is not limited to a certain material, yet, many other materials can be made more interesting, interactive, and communicative.

\section{REFERENCES}

[1] Subagia, I Wayan. 2003. Masalah-Masalah Penerapan Model Pembelajaran Sains Dengan Pendekatan Starter Eksperimen (PSE) Dalam Pembelajaran Sains Di Sekolah Dasar. Jurnal Pendidikan dan Pengajaran IKIP Negeri Singaraja, No. 4 TH. XXXVI Oktober 2003.

[2] Gillies, Robyn, Boyle, Michael. 2010. Teachers' Reflections on Cooperative Learning: Issues of Implementation. Teaching and Teacher Education: An International Journal of Research and Study. 26 (2010) p. $933-940$.

[3] Wyk, Micheal M van. 2012. The Effects of the STAD Cooperative Learning Method raon Student Achievement, Attitude and Motivation in Economics Education. Journal Social Science, 33(2): 261-270 (2012)

[4] Smyrni, Panagiota, Nikopoulou and Nikopoulos, Christos. (2010). Evaluating the impact of video-based versus traditional lectures on student learning. International Research Journals. (ISSN: 2141-5161) Vol. 1(8) pp. 304-311 September 2010.

[5] Dyson, Ben. 2002. The Implementation of Cooperative Learning in an Elementary Physical Education Program. Journal of Teaching in Physical Education, 2002, 22, 69-85.

[6] Draf Kurikulum 2013. Kementerian Pendidikan Dan Kebudayaan. Desember 2012.

[7] Salinan Lampiran Peraturan Menteri Pendidikan Dan Kebudayaan Republik Indonesia Nomor 65 tahun 2013 tentang Standar Proses Pendidikan Dasar Dan Menengah.

[8] Peraturan Menteri Pendidikan Nasional Republik Indonesia Nomor 41 tahun 2007 tentang Standar Proses.

[9] Peraturan Pemerintah Nomor 23 tahun 2013 tentang Standar Nasional Pendidikan.

[10] Miles and Huberman. 1992. Analisis Data Kualitatif. Jakarta UI Press.

[11] Riyana, Cheppy. 2007. Pedoman Pengembangan Media Video. Jakarta: P3AI UPI 
PRESS

[12] Sanjaya, Wina. 2010. Strategi pembelajaran berorientasi standar proses pendidikan. Jakarta: Kencana Prenada Media Group. 